Acta Regionalia et Environmentalica 1

Nitra, Slovaca Universitas Agriculturae Nitriae, 2016, pp. 6-11

\title{
ARSENIC POLLUTION STUDY AT NITRA-KRŠKANY LOCATION AS AN EXAMPLE OF LINE CONTAMINATION
}

\author{
Michal VARGA, Marek KOLENČÍI* \\ Slovak University of Agriculture in Nitra, Slovak Republic
}

\begin{abstract}
The aim of this article was to identify the level of arsenic in soils and water as a type of line contamination with widespread environmental impact. For this purpose, as the "model locality" was chosen the Nitra River (Krškany location situated around $80 \mathrm{~km}$ from the original source of contamination - Zemianske Kostolany). EcaFlow 150 analyzer was used to identify the content of arsenic in water and soil samples, SEM and EDS were used to characterize morphology, surface area, and chemical composition of primary substrate. In Nitra-Krškany, significant values of arsenic concentrations were observed for surface water, $14.75 \mu \mathrm{g}$ $\mathrm{I}^{-1}$, which exceeded the WHO international A limit 1.5 times, for filtered water from the sediment, $149.9 \mu \mathrm{g} \mathrm{I}^{-1}$, with the present exceedance in all categories (WHO international A limit 15 times), and for soil samples, $26.6 \mathrm{mg} \mathrm{kg}^{-1}$, which exceeded 2.6 times the Slovak soil legal limit $\left(10 \mathrm{mg} \mathrm{kg}^{-1}\right)$. Detection of arsenic confirmed line contamination in Nitra - Krškany. As the main source responsible for contamination there was evaluated coal combustion residuals that consist of spherical aggregates from $2 \mu \mathrm{m}$ to $1 \mathrm{~mm}$ dimension, non-linear topography. This type of contamination has a long-term impact due to hazardous materials and nonstable reactive surface area.
\end{abstract}

Keywords: environmental impact, arsenic, line contamination, coal combustion residuals, Nitra River

In environmental sub-systems, there are localized various types of interactions (Campbell et al., 2014). Widespread man-made activities input to environment many anthropogenic substances, which play a key role influencing energy flows and changes in material composition of environmental sub-systems (Gadd, 2010). This effect can be observed in a number of areas worldwide (Nordstrom, 2002). However, arsenic distributions were identified in many Slovak localities in natural geological substrates and also with generated man-made anthropogenic activities. One of the impacted localities is the Horná Nitra region, heavily affected by human activities, mainly mining and chemical industry. For a long period of time, lower quality brown coal and lignite has been used in this area. Lignite contains diverse mineral association, including sulfide minerals. These are commonly represented by pyrite $\left(\mathrm{Fe}_{2} \mathrm{~S}\right)$, arsenopyrite $(\mathrm{FeAsS})$, realgar $\left(\mathrm{As}_{4} \mathrm{~S}_{4}\right)$, enargite $\left(\mathrm{Cu}_{3} \mathrm{AsS}_{4}\right)$, nickeline (NiAs), cobaltine (CoAsS) associated with elements such as iron, arsenic, antimony, selenium, zinc, copper, nickel, and other environmentally hazardous elements (Smedley and Kinnburgh, 2002). During thermal treatment combustion, various types of pollutants are emitted to the air (volatilized phases), as well as less heterogenous materials, silicate glasses, alloys, ash (more or less thermodynamically stable phases) are generated (Pandey et al., 2011; Jurkovič et al., 2008). One of the environmental strategies is to prevent the distribution of contamination which may pose environmental hazard in long term perspective. For this reason, environmentally hazardous materials are accumulated in one place and involve dumps, tailings, and other in-site or ex-situ remediation areas. On 21 May 1965, dam used to store coal combustion coal combustion residuals was undermined due to heavy rain and technical concerns. Dam had no ability to withstand constant pressure of coal combustion residuals mixed with water. To the river Nitra leaked 2.5 million cubic meters of coal combustion residuals mixture and was washed away around its upper reaches (Jurkovič et al., 2008). There is some evidence that in the river basin there are situated fields that are usually used for agricultural production. Also, the river flows through many sites in which inhabitants use water from the river Nitra. Arsenic in water used for drinking or irrigation purposes can cause significant health problems as it tends to have a long-term effect on the environment.

Arsenic concentration depends on many environmental and thermodynamic conditions, such as $\mathrm{pH}$, Eh, the activity of microorganisms. Considerable stability and reactivity could be influencing with various geochemical barriers such as $\mathrm{Mn}, \mathrm{Fe}, \mathrm{Al}$ oxides and hydroxides, content of clay components, humic substances and etc. (Suda and Makino, 2016), which determine the speciation, distribution, abundance, bioavailability, and the potential toxicity of elements. The relationship between chronic health effects and arsenic exposure has been well proven (Yoshida et al., 2004). Trivalent arsenic species inhibit enzymatic processes, including, for example, glycolysis. Pentavalent species of arsenic inhibit oxidative phosphorylation on 
mitochondria (addition of phosphate group to a protein or other molecule) (Pant and Rao, 2010). Absorbed arsenic is captured by liver and kidneys (have cumulative character), in which small amounts are stored, bioaccumulated. Arsenic is also transported to heart and lungs and in small amount accumulated in muscles and nerve fibers (Klaassen, 1996). Higher amounts of arsenic can be found in skin, hair, and nails, where it is bounded to sulfhydril keratin groups (Smedley and Kinniburgh, 2002).

Monitoring the input and output cycles of arsenic into the system is an important knowledge to prevent point source, non-point source, and also line contamination. Line contamination transported via river water can occur on area of several tens or hundreds of kilometers where it interacts with various components of the environment (soil, fauna, flora, micro-organisms, including human health). Water (aquatic medium) acts as a reactive medium, where can be dissolved various substances and transported for several kilometers from the source of contamination. Chemical reaction kinetics is more intensive under turbulent conditions, where disperse systems with a dynamic regime are obtained, while gradually releasing their energy, and, therefore, sediments can be re-deposited and accumulated in the upper level of soils. Character of re-deposited material is exposed to new microbial, chemico-physical and other environment changes. These conditions and factors support the generation of the most negative bioavailable and potential toxic forms to biological systems.

For these reasons the aims of the study were to identify the level of arsenic (As) contamination, through EcaFlow 150 analysis, as detection of line pollution in the locality of the river Nitra (Nitra-Krškany), and evaluate the potential further environmental impact to other systems. Scanning Electron Microscopy (SEM) was used for morphology, surface area, and Electron Dispersive Spectroscopy (EDS) for chemical analysis of the primary substrate - combustion coal combustion residuals, which was responsible for primary contamination.

\section{Material and methods}

\section{Locality description}

The locality is the type of residential and agricultural area that uses water from the river for various purposes (Horák and Šiška, 2006). The study area is positioned between the river Nitra and the river branch called Malá Nitra at latitude $48.27321^{\circ} \mathrm{N}$ and longitude of $18.10514^{\circ} \mathrm{E}$ (Figure 1).

River Nitra floodplain consists of Holocene fluvial sediments (mostly loamy and clayey loamy flood sludge, slightly sandy sediments). Floodplain thickness reaches $2-5 \mathrm{~m}$, bedrock is formed by Pleistocene sand-gravel sediments with thickness 5-8 m.

\section{Samples and their preparation}

The samples were collected (Figure 2 ), preserved and transported in accordance with ISO 5667-3:2012. Collection includes samples of water, soil, and water sediments were collected in the time period December 2013 and April 2014 and analysis of samples was carried out in triplicate.

The soil samples were dried, crushed and organic components were removed according to the methodology (NCERA-13, 2012). The total amount of samples was dissolved in $2 \mathrm{M} \mathrm{HNO}_{3}$ according to the methodology by Borosova et al. (2010). EcaFlow 150 was used to carry out quantitative analysis of arsenic in samples according to the methodology by Urminská et al. (2010).

\section{Materials}

All chemicals were analytical grade: $\mathrm{HCl}, \mathrm{NaOH}, \mathrm{HNO}_{3}, \mathrm{H}_{2} \mathrm{O}, \mathrm{KCl}$ (FISHER Slovakiaspol s. r. o., Sigma Aldrich s.r.o.), standard solutions R-101 and $\mathrm{KMnO}_{4}$ (Istran s. r. o., Slovak Republic), Blue No. 1 filter paper (FILPAP, Czechia) was used to filtration procedure which separated water samples from solid residues (soils and sediments).

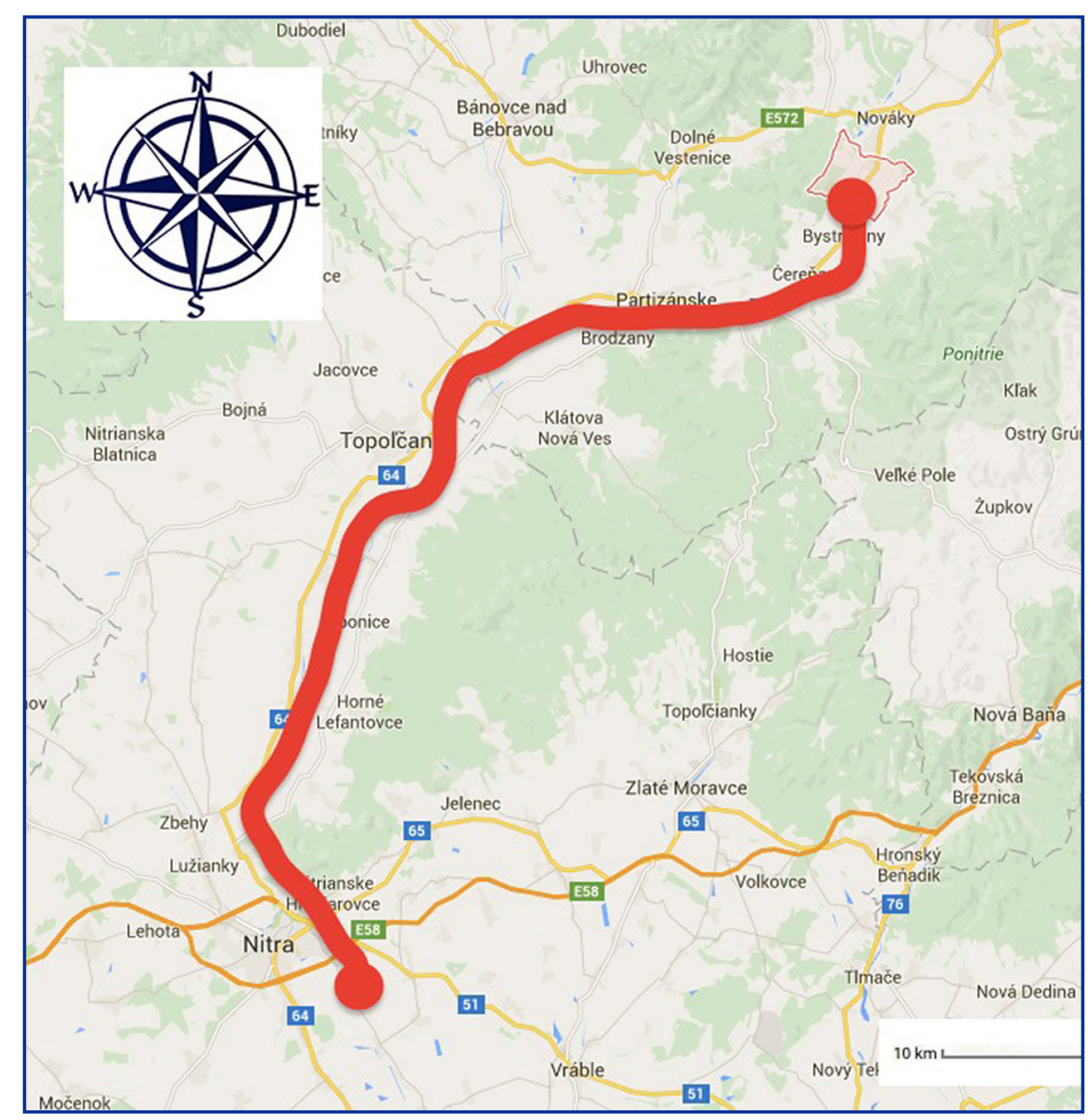

Figure 1 Displaying line contamination of arsenic marked by the red line (the primary source of contamination Zemianske Kostolany and locality of arsenic detection in Nitra - Krškany). As shown in the picture, the sites are distant more than $80 \mathrm{~km}$ Source: maps.google.com 


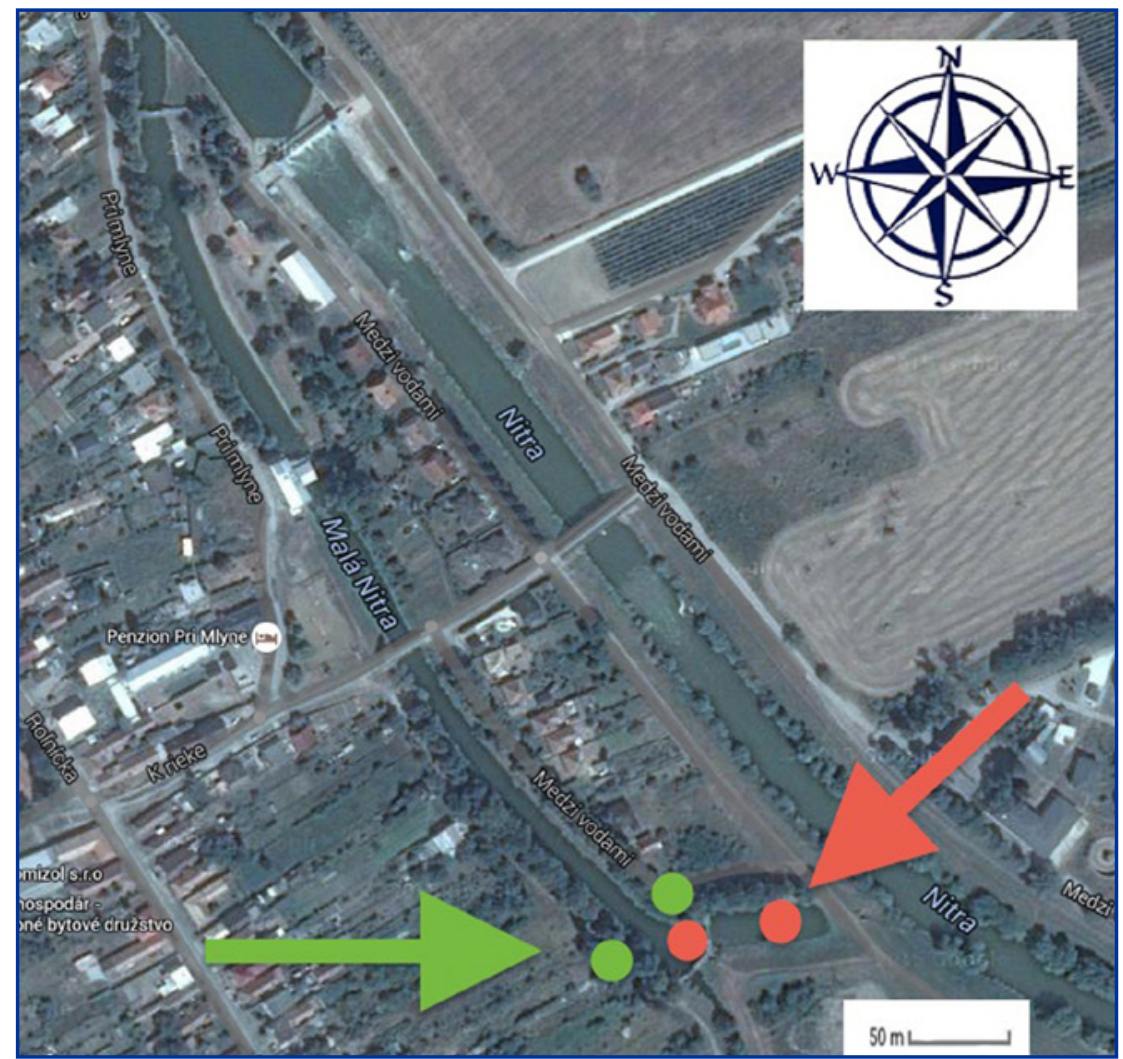

Figure 2 Displaying detailed map of Nitra - Krškany with place of soil and water sampling. Green arrow marks collection place of soil samples and red arrow marks collection place of water and sediment samples Source: maps.google.com

Analytical methods - EcaFlow, SEM, EDS and $\mathrm{pH}$ measurement

EcaFlow uses electrode coulometric titration and is based on the direct electrochemical conversion of the analyte species in the pores of the electrode or in a thin layer, which is used for the analysis of metals and heavy metals (Kolenčík et al., 2011, Urminská et al., 2010).

Scanning Electron Microscopy (SEM) was used to characterize morphology and particle size distribution, topography surface area of the primary substrate from Zemianske Kostolany. SEM had optimized parameters of measurement at accelerating voltage $15 \mathrm{keV}$ and sampling current 5-10 nA (Buc et al., 2007). SEM analysis is based on the principle of secondary emitted electrons. Electron Dispersive Spectroscopy (EDS) was used for qualitative chemical analysis to detect main and trace elements according to Ružička et al. (2012). EDS analysis was used in conjunction with scanning electron microscopy. The EDS technique detects $X$-rays emitted from the sample during the bombardment by an electron product of incomplete combustion of lignite. Accordingly, one of the surface phenomena is bonding of metals $(\mathrm{Pb}$, $\mathrm{Zn}, \mathrm{Cu}$, and etc.) and metalloids ( $\mathrm{As}, \mathrm{Sb}$, $\mathrm{Se}$, and etc.) on spherical shape with specific pore topography, small size, and character of interfaces (Pandey et al., 2011). The changes of internal and external environmental conditions could accelerate mobilization of metalloids, such as arsenic, in terrestrial and aquatic sub-systems. Measurable range versus pore topography of grains underline further considerable factor of arsenic sorption or desorption processes (Singh and Pant, 2006). The size of coal combustion residuals from Zemianske Kostolany ranges from $1 \mathrm{~mm}$ to $<10 \mu \mathrm{m}$. Similar particle size distribution and morphology of coal and fly ash was confirmed from Black warrior basin in Alabama and also contained $\mathrm{Se}, \mathrm{Hg}, \mathrm{As}$, $\mathrm{Pb}, \mathrm{Sb}, \mathrm{Co}, \mathrm{Cr}, \mathrm{Ni}, \mathrm{U}$, and other hazardous elements (Zielinski et al., 2007). The coal combustion residuals from Zemianske Kostolany and also in similar materials have a high content of vitreous materials and carbonized spherical grains where arsenic could be directly or indirectly included (Petková et al., 2011; Bundschuh et al., 2005). Generally, glass substances pose non-stable crystalline phases with relatively high devitrification potential (disintegration of glass) and thus mobilization of included elements may occur.

The results of chemical analysis of the coal combustion residuals have shown that the material is not homogeneous and has variable content of essential, and hazardous elements $(\mathrm{O}, \mathrm{Si}, \mathrm{Al}, \mathrm{Mg}, \mathrm{Ca}, \mathrm{Fe}, \mathrm{K})$, associated with As (Figure 4 and Figure 5). Mineral composition of the parent materials from Zemianske Kostolany (Figure 3) has varied forms. In comparison with our analysis, authors Pet'ková et al. (2011) discovered that the most abundant elements were $\mathrm{Fe}, \mathrm{Ca}, \mathrm{Al}, \mathrm{Mg}$, $\mathrm{K}, \mathrm{Ti}, \mathrm{Na}, \mathrm{S}, \mathrm{P}, \mathrm{Mn}$, Si with small content of trace elements involving $\mathrm{As}, \mathrm{Cu}, \mathrm{Zn}$, $\mathrm{Ni}, \mathrm{Co}, \mathrm{Pb}$, and $\mathrm{Sb}$.

These elements depending on many diverse conditions and exposition times may have negative impacts towards biological systems. Bioavailability and potential toxicity may be increased due to pronounced accumulation of trace elements, changing speciation, distribution, abundance and etc. Participation of detected hazardous 


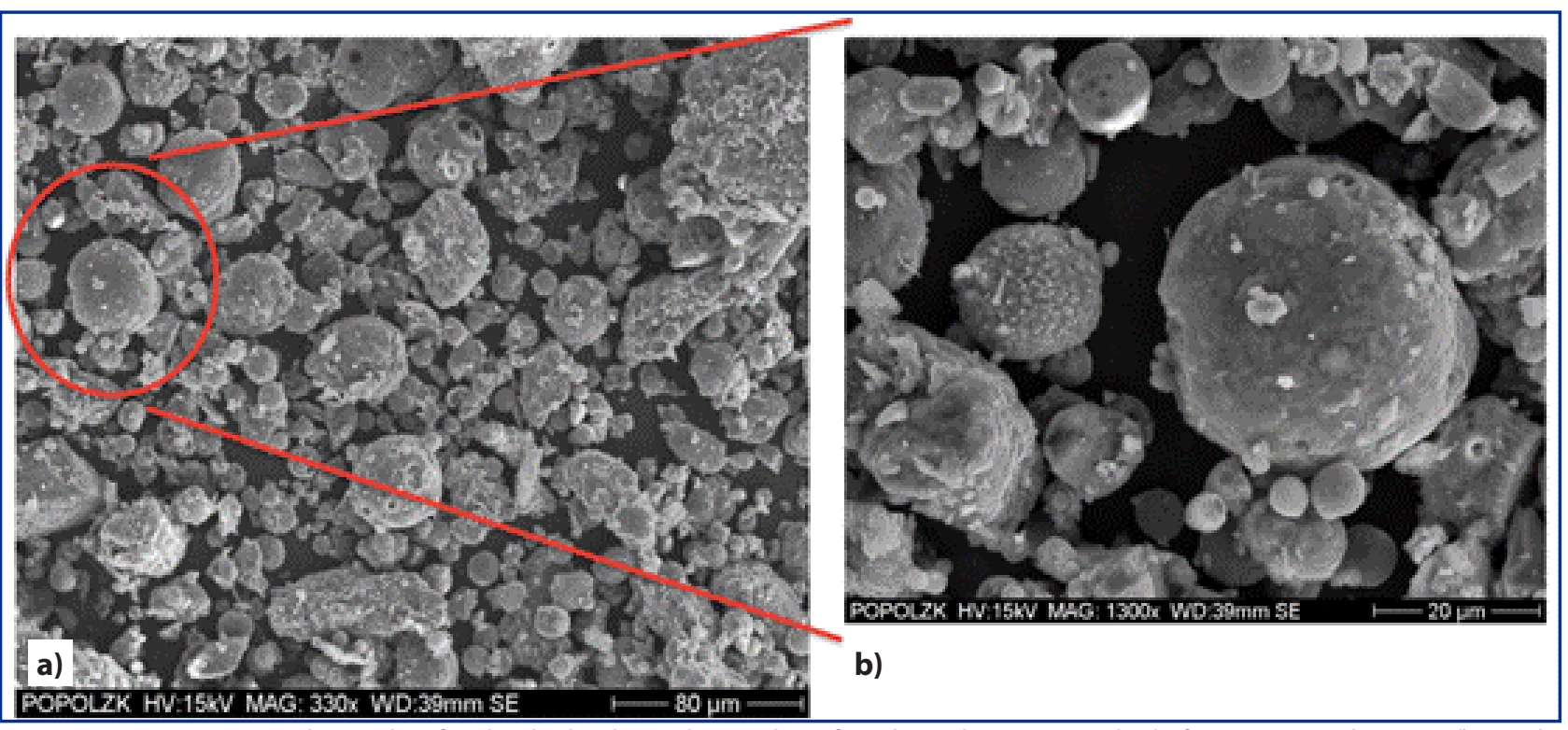

Figure 3 a) A typical sample of individual spherical particles of coal combustion residuals from Zemianske Kostolany, 3b) Detail of the individual grains

Source: Scanning Electron Microscopy (SEM)

elements (As, $\mathrm{Cu}, \mathrm{Ni}, \mathrm{Al}$ ) associated with Pet'ková et al. (2011) $(\mathrm{Cu}, \mathrm{As}, \mathrm{Ti}, \mathrm{Zn}, \mathrm{Co}, \mathrm{Pb}, \mathrm{Sb})$ could have significant impact on potential toxicity. As was mentioned before, the high content of copper was demonstrated in the parent material from Zemianské Kostol'any.

Copper in high concentration may cause the destruction of red blood cells, protein breakdown, spleen and liver damage, and can lead to the Alzheimer's disease (Fraga, 2005) and inhibits enzymatic processes for collagen synthesis, by displacing elements. In enzymatic pathways the copper has antagonistic effects with zinc, and high concentration of Cu can cause a deficiency of zinc, which is an essential element important in enzyme creating processes, synthesis of carbohydrates, lipids and proteins. Chronic exposure at high doses has a cumulative effect and causes a deficiency of $\mathrm{Cu}$, hematological changes, and binds to metal-proteinattenuating compounds (Ritchie et al., 2004).

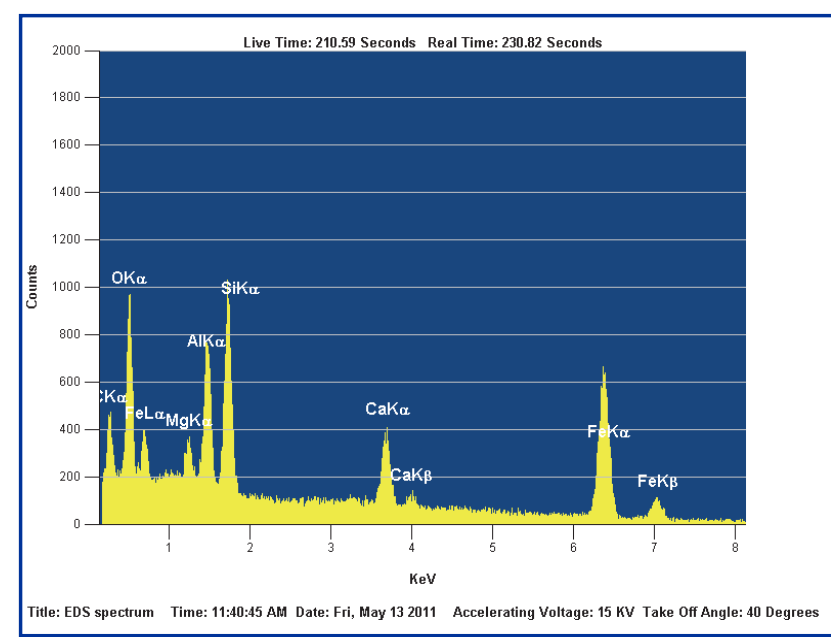

Figure 4 Chemical composition of coal combustion residuals, main analyzed elements were $\mathrm{Si}, \mathrm{K}, \mathrm{Al}$, $\mathrm{O}, \mathrm{Ca}, \mathrm{Fe}, \mathrm{Mg}$

Source: Electron Dispersive Spectroscopy (EDS)
Aluminum due to electric charge often inhibits essential elements with similar characteristics in human body, such as $\mathrm{Mg}, \mathrm{Ca}$ and Fe. The chronic exposure can cause muscle pain, bone pain, joint pain, bone tissue loss, and reduced amount of calcium (Winship, 1993).

Other elements in various concentrations were detected in the parent material and depending on environmental conditions, they may be transformed, translocated, and transported and result in mobilization of stable and nonstable elements in aqueous medium.

\section{Current status of the environmental impact of As on the site Nitra-Krškany as a type of line contamination}

At the Nitra-Krškany locality, arsenic was identified in water and soil samples. Location is situated about $80 \mathrm{~km}$ from Zemianske Kostolany, which poses significant line pollution

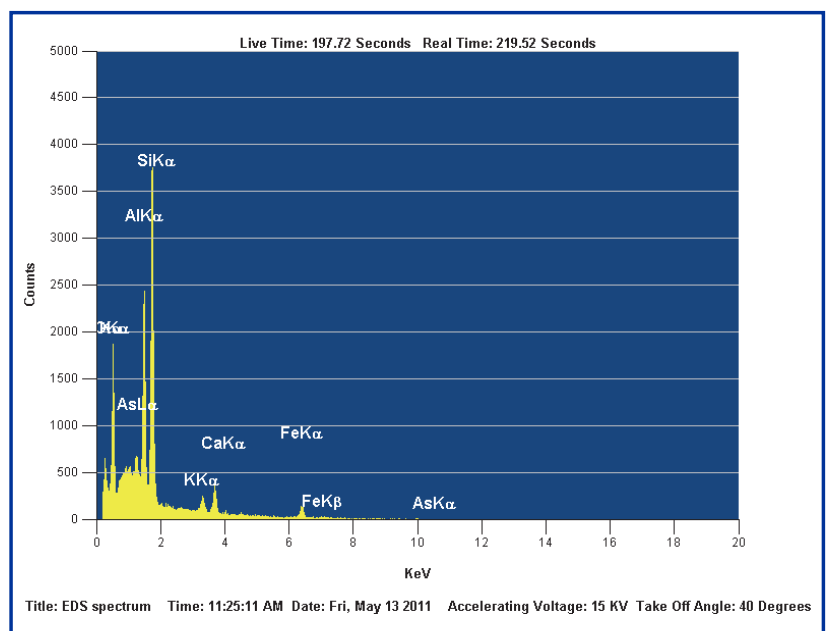

Figure 5 Chemical composition of coal combustion residuals, main analyzed trace elements were As, $\mathrm{Si}, \mathrm{Al}, \mathrm{Ca}, \mathrm{Fe}$ Source: Electron Dispersive Spectroscopy (EDS) 


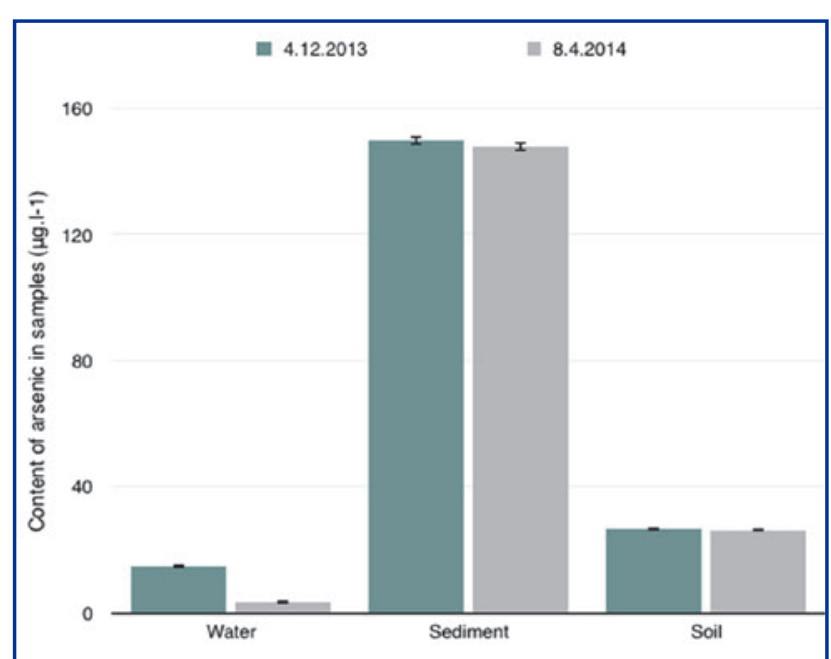

Figure $6 \quad$ Measured values in the water and soil samples under water, taken in two terms. Analysis EcaFlow. Results: water $14.75 \mathrm{\mu g} \mathrm{l}^{-1}$ ( \pm 0.035),

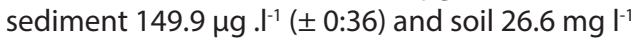
$( \pm 0.06)$

Source: Electron Dispersive Spectroscopy (EDS)

(Figure 1) (type of line contamination). Soil and water samples were analyzed for arsenic content and results can be seen in Figure 6.

Surface water samples collected in December 2013 (14.75 $\mu \mathrm{g} \mathrm{I}^{-1}( \pm 0.035)$ up to 1.5 times) exceed the recommended limit by WHO of arsenic for surface water intended for drinking purposes in category $\mathrm{A} 1\left(10 \mathrm{\mu g}^{-1}\right)$ (Robinson et al., 2003). The detected content of arsenic in surface water was collected in April 2014 and has value $3.27 \mathrm{\mu g} \mathrm{I}^{-1}$ $( \pm 0.008)$ which means no exceedance in any WHO category $(A, B, C)$. This interesting phenomenon may be affected by binding to the geochemical barriers of $\mathrm{Fe}, \mathrm{Mn}, \mathrm{Al}$ oxides and hydroxides, microbiological activity, daily temperature, insolation and other factors (Yurkevich et al., 2012; Suda and Makino, 2015). The most likely influenced factor could be changed in water level (water medium e.g. turbulence), and, therefore, accommodate from static to dynamic regime.

In water from sediment, the content of arsenic reached $149.9 \mathrm{Mg} \mathrm{I}^{-1}( \pm 0.36)$, which means exceedance limits in all categories (269/2010 Z.z.). In comparison with our data, the results by Postma et al. (2010) from the Red River in Vietnam varied from 70 to $100 \mathrm{~g} \mathrm{l}^{-1}$. According to the authors, arsenic was released through reduction of Fe-oxides and hydroxides by microbiological processes where arsenic was previously bounded to the iron species. Similar results were achieved by Xie et al. (2012) for the long term accumulation of water sediments from arsenic contaminated sites. In some cases, the value of As in groundwater exceeded $500 \mathrm{~g} \mathrm{l}^{-1}$.

Total content of arsenic in soil samples in our case was 26.6 $\mathrm{mg} \mathrm{kg}^{-1}( \pm 0.06)$ by which the limit, according to the Slovak law (59/2013 Z.z.), was exceeded 2.6 times. Almost analogous result was presented by Gutiérrez-Ruiz et al. (2012).

Stability and mobility of arsenic in environment depend on $\mathrm{pH}$ conditions (Gadd, 2010). In our survey, the $\mathrm{pH}$ of the measured water samples ranged from 7.14 to 8 which is a neutral to slightly alkaline water, and the soil sample had almost similar $\mathrm{pH}$ value ( $\mathrm{pH}$ 7.4). In our case, at neutral to slightly alkaline waters, arsenic could be most often found in inorganic species such as $\mathrm{H}_{3} \mathrm{AsO}_{3}, \mathrm{HAsO}_{4}^{2-}$ and $\mathrm{H}_{2} \mathrm{AsO}_{4}^{-}$. Another environmentally important species can be found in other trivalent and pentavalent species, found in organically bounded formations, acids, or can be volatile (Guo et al., 2008). Acidification of soils and waters has a significant effect on bioavailability of As because binding elements become more soluble. With decreasing $\mathrm{pH}$ availability, As for the plants is increasing due to mineral dissolution and following crystal structure deterioration. On the other hand, the increase of $\mathrm{pH}$ may result in the desorption of arsenic due to reduced stability of the arsenic on the geochemical barriers such as Fe, Mn, and Al metal oxide and other sorptionable complexes (Raven et al., 1998). Change in $\mathrm{pH}$ may change oxidation state of $\mathrm{As}^{5+}$ to $\mathrm{As}^{3+}$. The mechanism of the reaction may also be affected by the presence of active microorganisms or their products, which can fully methylate As compounds in wide $\mathrm{pH}$ range (Čerňanský et al., 2009).

It could be presumed that the significant arsenic transformation activity at the neutral $\mathrm{pH}$ conditions is caused by other accompanying geochemical cycles, fate, and processes located in sediment-water-microorganisms. The dominant processes related to arsenic water and sediment content are biosorption, bioaccumulation to algae, fungi, bacteria, in situ vegetation, fish, and other habitants (Xie et al., 2012). Most likely, there could be exceeded content of other heavy metals and metalloids that were originally detected in parent material.

\section{Conclusion}

The content of arsenic in surface water and sediment was detected in the Nitra-Krškany locality for all studied cases. Water samples from December 2013 exceeded the limit values $14.75 \mathrm{\mu g} \mathrm{l}^{-1}$, and sample from April 2014 was $3.27 \mathrm{~g} \mathrm{I}^{-1}$. In the water filtered from the sediment, the average concentration of arsenic was $149.9 \mathrm{\mu g} \mathrm{I}^{-1}$, which indicates exceeding all of the legal limits stipulated by WHO (A, B, C). In soil samples, there was determined the total content of arsenic $26.6 \mathrm{mg} \mathrm{kg}^{-1}$ and, therefore, they exceed the limit 2.6 times. The parent material as a source of pollution came from Zemianske Kostolany, which is located more than $80 \mathrm{~km}$ from the studied location. Also, the nature of these hazardous materials plays a key role to support the long-term type of line contamination. Morphological characteristics of primary materials demonstrated the occurrence of spherical aggregates of morphologically distinct grains, with similar porous and non-linear topography and with variable reactive surface area. The size composition of the fly ash from Zemianske Kostolany ranges from $1 \mathrm{~mm}$ to $<10 \mu \mathrm{m}$. Chemical analysis of the fly ash showed that the material is not homogeneous, and represents heterogenous mixture of variable composition with most abundant elements such as $\mathrm{O}, \mathrm{Si}, \mathrm{Al}, \mathrm{Mg}, \mathrm{Ca}, \mathrm{Fe}, \mathrm{K}$, and fluctuating content of As. In this locality, it could be profitable to realize further detailed survey including monitoring of other heavy metals (metalloids) with emphasis on their translocation, transport pathways, biological availability, and application of suitable remediation measures.

\section{Acknowledgement}

Our acknowledgment is to Ing. Mária Čaplovičová, CSc. for SEM images and EDS analysis and to RNDr. Lubomír 
Jurkovič, PhD. for samples of the coal combustion residuals from Zemianske Kostol'any.

\section{References}

BOROSOVA, D. - MANOVA, A. - MOCAK, J. - BEINROHR, E. 2010. Determination of nicel in hair samples by graphite furnace atomic absorption spectroscopy and flow-through stripping chromopotenciometry. In Analytical Methods, vol. 2, 2010, pp. 1913-1917.

BUC, D. - BELLO, I. - ČAPLOVIČOVÁ, M. - MIKULA, M. - KOVÁČ, J. HOTOVÝ, I. -CHONG, Y. M. - SIU, G.G. 2007. Analysis of magnetron sputtered boron oxide films. In Thin Solid Films, vol. 515, 2007, no. 24, pp. 8723-8727.

BUNDSCHUH, J. - FARIAS, B. - MARTIN, R. - STORNIOLO, A. BHATTACHARYA, P. - CORTES, J. - BONORINO, G. - ALBOUY, R. 2005 Relevance, essentiality and toxicity of trace elements in human health. In Molecular Aspects of Medicine, vol. 26, 2005, pp. 235-244. CAMPBELL, D.E. - LU, H. - LIN, B. 2014. Emergy evaluations of the global biogeochemical cycles of six biologically active elements and two compounds. In Ecological Modeling, vol. 271, 2014, pp. 32-51.

ČERŇANSKÝ, S. - KOLENČÍK, M. - ŠEVC, M. - URÍK, J. - HILLER, E. 2009. Fungal volatilization of trivalent and pentavalent arsenic under laboratory conditions. In Bioresource technology, vol. 100, 2009, no. 2, pp. 1037-1040.

FISHER, M.M. - REDDY, K.R. 2014. Soil pore water sampling methods. In Methods in Biogeochemistry of Wetlands, vol. 10, 2014, pp. 50-70.

FRAGA, C.G. 2005. Relevance, essentiality and toxicity of trace elements in human health. In Molecular Aspects of Medicine, vol. 26, 2005, pp. 235-244.

GADD, G.M. 2010. Metals, minerals and microbes: geomicrobiology and bioremediation. In Microbiology, vol. 156, 2010, pp. 609-643.

GUO, H. - YANG, S. - TANG, X. - LI, Y. - SHEN, Z. 2008. Groundwater geochemistry and its implications for arsenic mobilization in shallow aquifers of the Hetao Basin, Inner Mongolia. In Science of The Total Environment, vol. 393, 2008, pp. 131-144.

GUTIÉRREZ-RUIZ, M.E. - CENICEROS-GÓMEZ, A.E. - VILLALOBOS, M. - ROMERO, F. - SANTIAGO, P. 2012. Natural arsenic attenuation via metal arsenate precipitation in soils contaminated with metallurgical wastes: II. Cumulative evidence and identification of minor processes. In Applied Geochemistry, vol. 27, 2012, pp. 2204-2214.

HORÁK, J. - ŠIŠKA, B. 2006. Evaluation of $\mathrm{N}_{2} \mathrm{O}$ emissions by DNDC model for sandy loam soils of danubian lowland. In Journal of Environmental Engineering and Landscape Management, vol. 14, 2006, no. 4, pp. 165-171.

JURKOVIČ, L'. - VESELSKÁ, V. - GUČKOVÁ, V. - FRANKOVSKÁ, J. 2008 Geochemické zhodnotenie kontaminácie pôd arzénom v oblasti Zemiankych Kostolian. In Acta Environmentalica Universitatis Comenianae (Bratislava), vol. 16, 2008, no. 1, pp. 47-55.

KLAASSEN, C.D. 1996. Heavy metals and heavy-metal antagonists. In Goodman and Gilmans: The pharmacological basis of therapeutics, $9^{\text {th }}$ edition. Eds.: J. G. Hardman, A. G. Gilman, L. E. Limbird. New York: McGraw-Hill, 1996, pp. 1649-1672.

KOLENČÍK, M. - ČEŇANSKÝ, S. - URÍK, M. - LITTERA, P. - ŠEVC, J. MOLNÁROVÁ, M. - GARDOŠOVÁ, K. - BAČíK, P. 2011. Chemické a mikrobiálne lúhovanie $M n$ z polyfázovej zlúčeniny arzeničnanov oxidov a hydroxidov mangánu. In Acta Environmentalica Universitatis Comenianae (Bratislava), vol. 19, 2011, no. 1, pp. 187-193.

NORDSTROM, K.D. 2002. Worldwide occurrence of arsenic in ground water. In Science, vol. 269, 2002, no. 5576, pp. 2143-2145.
PANDEY, C.V. - SINGH, J.S. - SINGH, R.P. - SINGH, N. - YUNUS, M. 2011. Arsenic hazards in coal fly ash and its fate in Indian scenario. In Resources, Conservation and Recycling, vol. 55, 2011, pp. 819-835.

PANT, H.H. - RAO, V.M. 2010. Evaluation of in vitro anti-genotoxic potential of melatonin against arsenic and fluoride in human blood cultures. In Ecotoxicology and Environmental Safety, vol. 73, 2010, pp. 1333-1337.

PEŤKOVÁ, K. - LALINSKÁ-VOLEKOVÁ, B. - JURKOVIČ, L'. - VESELSKÁ, V. 2011. Chemické a minerálne zloženie elektrárenských popolov (lokalita Zemianske Kostolany). In Mineralia Slovaca, vol. 43, 2011, pp. 377-386.

POSTMA, D. - JESSEN, S. - HUE, T.M.N. - DUC, T.M. - KOCH, B.CH. VIET, P.H. - NAH, Q.P. - LARNSEN, F. 2010. Mobilization of arsenic and iron from Red River floodplain sediments, Vietnam. In Geochimica et Cosmochimica Acta, 2010, no.12, pp. 3367-3381.

RAVEN, K.P. - JAIN, A. - LOEPPERT, R.H. 1998. Arsenite and arsenate adsorption on ferrihydrite: kinetics, equilibrium, and adsorption envelopes. In Environmental Science \& Technology, vol. 32, 1998, pp. 344-349.

RITCHIE, C.W. - BUSH, I.A. - MASTERS, C.L. 2004. Metal-protein attenuating compounds and Alzheimer's disease. In Expert Opinion on Investigational Drugs, vol. 13, 2004, no. 12, pp. 1585-1592.

ROBINSON, B. - DUVIG, C. - BOLAN, N. - KANNATHASAN, M. SARAVANAN, A. 2003. Uptake of arsenic by New Zealand watercress (Lepidium sativum). In The Science of Total Environment, vol. 301, 2003, no. 67-73, pp. 67-73.

RUŽIČKA, P. - DURMEKOVÁ, T. - HAIN, M. - ČAPLOVIČOVÁ, M. BÁGEL, L. - BAČÍK, P. - PUTIŠ, M. 2012. Vplyv kryštalizácie síranu sodného na intergranulárnu deštrukciu thassoského mramoru. In Acta Geologica Slovaca, vol. 4, 2012, pp. 155-169.

SINGH, T.S. - PANT, K.K. 2006. Solidification/stabilization of arsenic containing solid wastes using portland cement, fly ash and polymeric materials. In Journal of Hazardous Materials, vol. B131, 2006, pp. 29-36.

SMEDLEY, P.L. - KINNIBURGH, D.G. 2002. A review of the source, behaviour and distribution of arsenic in natural waters. In Applied Geochemistry, vol. 17, 2002, no. 5, pp. 517-568.

SUDA, A. - MAKINO, T. 2016. Functional effects of manganese and iron oxides on the dynamics of trace elements in soils with a special focus on arsenic and cadmium. In Geoderma, vol. 270, 2016, pp. 68-75.

URMINSKÁ, J. - POHRAJAŠOVÁ, J. - ONDRIŠÍK P. 2010. Stanovenie koncentrácie $\mathrm{Cd}, \mathrm{Pb}$, a As princípom prietokovej elektrochémie v sedimentoch, vo vybraných vodných nádržiach BanskoŠtiavnického regiónu. In Chemické Listy, vol. 104, 2010, pp. 807-810. WINSHIP, K.A. 1993. Toxicity of Aluminium. In Toxicology Revue, vol. 12, 1993, no. 3, pp. 177-211.

XIE, Z. - Wang, Y. - Xie, X. - Su, Ch. 2012. Arsenic resistance and bioaccumulation of an indigenous bacterium isolated from aquifer sediments of Datong Basin, Northern China, In Geomicrobiology Journal, vol. 30, 2012, no. 6, pp. 549-556.

YOSHIDA, T. - YAMAUCHI, H. - FAN SUN, G. 2004. Chronic health effects in people exposed to arsenic via the drinking water: Dose - response relationships in review. In Toxicology and Applied Pharmacology, vol. 198, 2004, no. 3, pp. 243-252.

YURKEVICH, N.V. - SAEVA, O.P. - PAL'CHIK, N.A. 2012. Arsenic mobility in two mine tailings drainage systems and its removal from solution by natural geochemical barriers, In Applied Geochemistry, vol. 27, 2012, pp. 2260-2270.

ZIELINSKI, R.A. - FOSTER, A.L. - MEEKER, G.P. - BROWNFIELD, I.K. 2007. Mode of occurrence of arsenic in feed coal and its derivative fly ash, Black Warrior Basin, Alabama. In Fuel, vol. 86, 2007, no. 4, pp. 560-572. 